\title{
Narrative and identity construction - an analysis of the L2 Learning process ${ }^{1}$
}

Luiz Antônio Caldeira Andrade

Universidade Federal de Minas Gerais - UFMG

RESUMO: A Aquisição de uma Segunda Língua (ASL) tem sido enfocada por vários pesquisadores que estudaram o processo sob diversas perspectivas (ex.: ELLIS, 1997; LANTOLF, 2000; GARDNER, 1968), para poderem interpretar como os aprendizes adquirem a L2. Entretanto, esses estudos têm se limitado aos processos cognitivos e a outros fatores (cultural e sócio-cognitivo, por exemplo), em vez de focalizar as experiências dos aprendizes. Em virtude disso, este estudo investiga as experiências de aprendizes por meio de um grupo de auto-narrativas registradas pelo Projeto AMFALE (Aprendendo com memórias de falantes e de aprendizes de línguas estrangeiras), tendo como suporte básico o trabalho desenvolvido por Leppänen e Kalaja (2002), no qual as autoras, com base na teoria de Vladimir Propp sobre a morfologia do conto de fadas (2000), investigam o processo de aprendizagem de L2 a partir de auto-narrativas que refletem o processo heróico, ainda que árduo, dos contos de fadas, detalhado por Propp. Para tanto, o artigo se divide em duas partes. A primeira faz uma breve revisão do processo de construção de identidade, da importância da narrativa autobiográfica como expressão de identidade, chegando, por fim, aos critérios de análise de autobiografias no processo de aprendizagem de L2, identificados por Leppänen e Kalaja (2002). A segunda parte do estudo analisa alguns exemplos de autobiografias do projeto AMFALE sob a luz das referidas teorias.

PALAVRAS CHAVE: Aquisição de segunda língua (L2), narrativas, identidade, conto de fadas, self.

ABSTRACT: Second Language Acquisition (SLA) has been the focus of many linguists who have studied the process through varied perspectives, (e.g. ELLIS, 1997; LANTOLF, 2000; GARDNER, 1968, to quote but a few) so that they may be able to interpret the way learners gather information regarding a second language process. However, such foci have been limited to cognitive processes and other factors (e.g. cultural, socio-cognitive) rather than placed on the learners' experiences themselves. In view of this, this paper investigates learners' experiences through the analysis of a group of self narratives recorded by the AMFALE (Aprendendo com memórias de

\footnotetext{
${ }^{1}$ I would like to express my thanks to Dr. Vera Lúcia Menezes de Oliveira e Paiva and Dr. Ricardo Augusto de Souza for their precious reading of the present article so that the readers could have it in its present form.
} 


\begin{abstract}
falantes e de aprendizes de língua estrangeira $)^{2}$ project, while, at the same time, analyzes such autobiographies in the light of Leppänen and Kalaja's (2002) work on autobiographies as learners' identities constructions, based on Vladimir Propp's book Morphology of the Folktale (2000). The study is divided in two parts: the first one briefly reviews the process of identity construction and the importance of autobiographies as a means of expression of the self. Besides, it also focuses on the criteria set forth by Leppänen and Kalaja (2002) for the analysis of autobiographies, based on Vladimir Propp's book Morphology of the folktale (2000). The second part focuses on the analyses of AMFALE autobiographies as stated above.

KEY-WORDS: second language acquisition, narratives, identity, fairy tales, self
\end{abstract}

\title{
PART I
}

\section{Introduction}

\section{Identity Construction}

Despite all the efforts made towards the world's globalization and the breaking down of geographical barriers, countries all over the world increasingly try to define their own identities in order to become a global reference, whether economical, cultural or political. However, "many identities are constructed exactly in the information exchange process with other cultural groups" (HAESBAERT, 2002). According to Clifford ${ }^{3}$ (apud URIARTE, 2002, p. 3), "a identidade é processual, isto é, nunca acabada. Não é uma herança, mas uma elaboração sempre contemporânea." ${ }^{״ 4}$ Uriarte (Ibid) further explains that "a identidade é processual porque é relacional e, portanto, negociada: ela se inventa "dentro de" e "contra" outros grupos e pessoas." As a matter of fact, the claim of identity being under ongoing construction is shared by both linguists and psychologists such as Rajagopalan (2002), Bamberg (2002), and Gergen (1997), to name some. Individuals try as well to find ways to set up their identities in order to survive

\footnotetext{
${ }^{2}$ AMFALE (Learning with Language Learning Histories - LLLH)

${ }^{3}$ CLIFFORD, J. Dilemas de la cultura. Antropología, literatura y arte en la perspectiva posmoderna. Barcelona: Gedisa, 1995.

4 "identity is a process, that is, never finished. It is not inherited but, rather, a construction that is always modern (My translation).

5 "It is a process because it is relational and, as a result, negotiated: it invents itself "within" and "against" other groups or individuals" (My translation).
} 
and also become a professional reference in such globalized and highly competitive market. But we search for our own identities not only for professional matters but also in order to achieve self-fulfillment and selfknowledge. Paradoxically, as the world walks towards its unification, relationships become more and more virtual and, consequently, people feel more and more lonely and away from relationships. So, in such a scenario, subjects see it as essential to their emotional and professional survival to get to know who they really are and to (re)negotiate their identities in order to be (re)inserted in this environment. Rajagopalan (2002) states that

De todas as identidades, a do indivíduo é a mais difícil de ser pensada diferentemente, isto é, como algo em constante processo de (re)construção. Afinal, numa cultura marcadamente individualista como a nossa, a crença na própria individualidade é entendida, não sem razão, como a primeira garantia de sobrevivência. ${ }^{6}$

However, this is a double-edged situation once it is important to investigate the ins and outs of identity just like mentioned by Murray (1995) when he referred to the constructionist view of identity posed by Shotter and Gergen (apud MURRAY, 1995) ${ }^{7}$ which claims that "identity is not only built up by the subject himself as a result of his outlook on the world, but it is also shaped by the world". No matter how hard we try to be ourselves within the groups we relate with, we are somehow affected and influenced by such groups: "embora crendo que tudo é construção e que se dá no entrelaçamento confuso, imprevisível e alinear dos gestos, à revelia, muitas vezes, dos nossos mais profundos desejos [...]" (RAJAGOPALAN, 2002) ${ }^{8}$

In this sociocultural frame, our identity is constructed as a result of "our decision to select, choose, and commit to different people and idea systems in the course of their activities" (PENUEL; WERTSCH9 apud GOVER, 1996).

6 "[...] the individual's identity is the most difficult one to be thought of differently, that is, as something under an ongoing (re)construction process, since, in a culture remarkably individualistic as ours, the belief in our own individuality is understood, and not by chance, as our basic guarantee of survival" (My translation).

${ }^{7}$ SHOTTER, J.; GERGEN, K. Texts of Identity. London: Sage, 1989.

8 " $[\ldots]$ though we believe that everything is construction and that it takes place in the confusing, unpredicted and non-linear sewing together of gestures, despite of our deepest wishes, many times [...]" (My translation).

${ }^{9}$ PENUEL, W. R.; WERTSCH, J. V. Vygotsky and identity formation: A sociocultural approach. Educational Psychologist, 30(2), p. 83-92, 1995. 
Our identities are, thus, reflections of the positions we assume in relation to the situations we live and the groups of people we interact with. That's the way the others see us and construct their opinions about us. We see this clearly in the professional environment: many executives are introduced at business meetings as being Mr. X from such and such company. Subjects identify themselves with their companies in so close a way that they have their last names substituted with the companies' names, making it impossible, many times, to dissociate the person from what (s)he does or where (s)he works. Harré10 (apud MURRAY, 1995) points that out referring to the problem of personal identity being difficult to a subject who gets to the point where it is hard to distinguish himself from the official social order.

Now, considering that our positions in the world are assumed also based on how we express ourselves, and having in mind that language is the most important means of such expression, as claimed by Rajagopalan (1998, p. 41-42) that the subject's identity is constructed in and through language, which, for its turn, is in constant evolution, we must turn to Bakhtin's (1988) social function of the language expression. According to him, the subject's inner world and reflection have their own well-established social audience in which the individual's thoughts, deductions, motivation, and the like, are constructed. He further states that our expression of ourselves is determined by the social relations we get into.

\section{Identity as a social construct}

As these relations change, so do our identities. And to assume a new identity, it is most likely that we lose our old identity. That is what Silva (2000, p. 82) means in "[a] afirmação da identidade e a marcação da diferença implicam, sempre, as operações de incluir e excluir". ${ }^{11}$ But such a loss does not mean that we cannot get our self back whenever we need it. As VeigaNeto (2000, p. 60) put it, "cada indivíduo tem várias identidades, cada uma das quais o enlaça com esse, aquele ou aqueloutro". ${ }^{12}$

\footnotetext{
${ }^{10}$ HARRÉ, R. Personal Being. Oxford: Basil Blackwell, 1983.

11 "Identity reassurance and difference highlighting always imply the inclusionexclusion exercise" (My translation).

12 "Each individual has many identities, each one of which connects him with one or another group" (My translation).
} 
Pavlenko; Lantolf (2000) talk of a loss of identity, subjectivities, frame of reference and the link between signifier and signified, and loss of the inner voice. This stage is followed by the recovery stage, that is, when the learner appropriates of others' voices, recreates his voice, first in writing, reconstruct his past, and continues to grow into new positions and subjectivities. They cite the story of Helen Jakobson, a Russian-American bilingual, who went through an "Americanization" process at all levels of her existence, losing not only "her family and familiar surroundings but also her ethnic, cultural and class identity".

\section{L2 and Identity Construction}

Identity as a result of social interaction and our loss of the old identity for a new one can be better evidenced when we try to use a language that is not our mother-tongue. Since we just cannot use the proper vocabulary and structure that would precisely and in a mature way express our feelings, we feel completely lost in our relations, unable to participate actively in any conversation, and ashamed of expressing ourselves childishly. This is a hindrance to most people's progress in their L2 learning. First, we do not like to be exposed and secondly, this fear assumes a greater proportion when we have to expose ourselves in an environment where we do not feel comfortable enough to act confidently. Vereza (2002) reports that in her investigation of undergraduates discourse in English at the Federal University of Rio de Janeiro, Brazil, she found out that they could not express their thoughts and feelings in the $\mathrm{L} 2$ wholly. She also reports that the students not only had the problem of trying to reach a native-like expression but also faced the problem of their identities constructed in their own language, that is L1. That comes as a support to Rajagopalan's (1998) claim mentioned earlier that without language it is simply impossible to have identity. According to Vereza (2002), "aprender uma língua é construir uma realidade para si mesmo, é impor alguma forma à experiência e, ao mesmo tempo, é ser construído e se construir para essa mesma realidade que só é acessível ao sujeito via língua."13

13 "learning a language is to construct one's own reality, to give form to experience, and, at the same time, to be constructed and to construct ourselves for this same reality which is only accessible to the subject through language" (My translation). 
A similar case, of a student being unable to express herself in English and interact with others, is presented by Ellis (1997) as he introduces the notions of subject to and subject of a discourse while citing Peirce's ${ }^{14}$ view of the relationship between social context and L2. In his example, a girl named Eva was unable to recognize a celebrity on the streets pointed at by a friend who could not understand how Eva had no idea who it was. According to Ellis, Eva "was subject to a discourse which assumed an identity she did not have." Still making reference to Peirce he argues that:

language learners have complex social identities that can only be understood in terms of the power relations that shape social structures [...] Learning is successful when learners are able to summon up or construct an identity that enables them to impose their right to be heard and thus become the subject of the discourse.

We all want to be able to express ourselves the way that most suits us. We want to be in control of our lives, and expressing ourselves in an L2 requires a lot of investment and courage, in order for us to become able to construct our identities in the language. Even in our own language, identities take time to be constructed, as we move on to create our social relations. The feeling of belonging in a place and a social group strengthens our self-confidence so that we feel more comfortable to take a step toward socialization.

Stories like that of Eva's have been under the attention of linguists so that they may better understand the factors that permeate the L2 learning process. Consequently, they have brought into focus L2 learners' account of their own learning process through their autobiographical narratives.

\section{Narrative as a means of identity construction}

Since the dawn of times stories have been told as a way of recording mankind's presence in the world. It is simply impossible to think of our life without them. They are the records of what we have been doing and who we have been since we came to existence. When we talk of a person's identity we, in fact, mean the person's life story, everything they lived that helped to compose their personalities. Lubeck (1998) states that story is a basic principle of our minds. He says that our thoughts, knowledge and experience are all organized as stories. According to him, we live in a

${ }^{14}$ PEIRCE, B. Social Identity, investment, and language learning. TESOL Quarterly, 29, p. 9-31, 1995. 
narrative way, organize our mental processes, and communicate with others by means of narratives.

Murray (1995), too, points out that one of the basic functions of selfnarratives is to relate the stories we live and tell to our identities, since those stories actually shape who we are. Pavlenko; Lantolf (2000) say that the same way narratives are constructed by communities so that they may make sense and provide cohesion for the community, individuals construct their own personal narratives to make their lives cohesive.

According to Bruner ${ }^{15}$ (apud BROCKMEIER; HARRÉ, 2003), one of the functions of narrative is to make the world subjective: it opens us to the hypothetical, to an array of real and possible perspectives which make up the genuine life of the interpretive mind. Thus, we have that narratives are part of peoples' cultures - they reflect one's way of living. Gover (1996) put it well when he affirmed that "[... the weaving together of events (past, present, and future) for purposes of meaning-making and identity construction is ultimately a narrative pursuit."

Narrative is fundamental because its elements relate to a set of human needs and concerns that must be answered before a life can go on, as defined by Lubeck (1998). And we only can go on constructing our lives when we become writers and protagonists of our own stories. On the other hand, at the same time that our narratives are constructed we are as well affected by our narratives. Ricoeur ${ }^{16}$ (apud CARVALHO, 2003) made it clear when he said that the subject is, at the same time, the writer and the reader of his own life. He argues that an individual's story of life is constantly under reconstruction by all the stories, whether fictional or real, that he tells about himself. But narrative, although told through the narrator's point of view, is directed to an audience and intended to reach this audience somehow. Ricoeur, when cited by Carvalho (2003, p. 4) made it very clear: "it is to share with the other a new experience".

\section{Autobiographies}

Leppänen; Kalaja (2002) in their study of Finnish university students of EFL say that "written autobiographies can be defined as a personal,

\footnotetext{
${ }^{15}$ BRUNER, J. S. Acts of Meaning. Cambridge, MA \& London: Harvard University Press, 1990.

${ }^{16}$ RICOEUR, P. Tempo e narrativa (tomo III). São Paulo: Papirus, 1997.
} 
chronological story by a first person narrator of a set of experiences for a specific purpose and audience." Based on Vladimir Propp's work on the Morphology of the Folktale (2000), they identified, as a result of their analysis of the autobiographies written by Finish students of EFL, five specific roles of the hero (a term coined by Propp and used by the authors to refer to the EFL learners) in their chronological recount of their experiences in learning a second language. Their recollections start with their first contact with the English language to date, and were labeled as thematic sequences as follows: (1) Acquisition without effort, in which the learner performs the role of the hero/in rather easily, that is, learns the FL without much problem or even help from others, as if s/he had a natural knack for it; (2) Learning as struggling, presenting our hero/in working hard to achieve her/his goals. It demands more of the part of the learner to master the language. However, Helpers ${ }^{17}$ are found to be qualified teachers, classmates and even methodologies that contribute to the learner's progress towards mastering the language; (3) Learning as infatuation, in which learners endure, without minding, all kinds of problems and difficulties in order to achieve the desired goal of mastering the language. Here, their love for the language increases as they move on towards improvement. Difficulties are overlooked as the learner's focus is on language proficiency. The authors even identify a certain "masochistic pleasure and desire in her/his efforts to master the language" (2002); (4) Learning as suffering, in which the learner adopts the role of Victim or Martyr, since learning the foreign language is extremely painful, despite the success achieved. Problems of all types are faced in the classroom with teachers, materials and classmates, lack of motivation due to the slow pace in class and few positive experiences; and finally (5) Learning as byproduct, in which the learner is described as the Antihero, since learning the language is not a goal in itself but just a means to achieve something else. Thus, the learner becomes more selective and critical of her/his learning process.

\footnotetext{
${ }^{17}$ Helper is a term coined by Propp to refer to any agent that might help the hero in his quest. [See Propp, Vladimir. Morphology of the Folk Tale (2000) for details on the terms used here].
} 


\section{PART II}

\section{The Project}

\section{The Development of the Study}

The study investigated the experiences of undergraduate students of EFL who took part in the AMFALE Project. The project was carried out at the Federal University of the state of Minas Gerais (UFMG) and comprised the analysis of narratives told by students learning a Second Language. Of all the narrative groups (e.g.: Portuguese, Teacher's narratives) we chose eighty (80) narratives written in English regarding the students' L2 learning process. The narratives selected were those which best illustrated the thematic sequences above, that is, described the roles the students themselves played and to those they assigned to others in the learning process. The work was based on Leppänen; Kalaja's (2002) model and Propp's (2000) theory, as we believe it to suitably mirror what the EFL/ESL learner goes through in his/her search of a new identity in the target language.

\section{Results of the Study and Analysis}

The narratives studied, some of which were copied here as originally written by learners, presented all the five types above, though not in the same percentage of occurrence as shown on TAB. 1 below. Each percentage, calculated by an elementary rule of three, corresponds to the number of occurrence of a specific type of thematic sequence, in relation to the total number of 80 narratives analyzed.

TABLE 1

Percentage of occurrence of thematic sequences reported by EFL students' autobiographies

\begin{tabular}{lcc}
\hline $\begin{array}{l}\text { Thematic } \\
\text { Number of }\end{array}$ & $\begin{array}{c}\text { Percentage } \\
\text { Occurrence }\end{array}$ & $\begin{array}{c}\text { Sequence } \\
\text { of Occurrence }\end{array}$ \\
\hline Acquisition without effort & 17 & $21,25 \%$ \\
Learning as struggling & 34 & $42,5 \%$ \\
Learning as infatuation & 12 & $15,0 \%$ \\
Learning as suffering & 11 & $13,75 \%$ \\
Learning as by-product & 6 & $7,5 \%$ \\
\hline
\end{tabular}


For example, the first type, Acquisition without effort, in which the learner performs the role of the hero/in rather easily, that is, learns the FL without much problem, was evidenced in the following examples:

(i)

My experience on learning English is not completed of course. But so far it's been great. I became really interested in English around 1990, when I was 13 yrs old. You can blame it all on videogames...

(ii)

My first contact with English took place when I was only five years old. At that time, I listened to the radio quite a lot and most songs were sung in English.

(iii)

I've never been in a classroom to learn English but I had hundreds of teachers. Virtually every American or Brazilian who knew more than me and with whom I came into contact was my teacher.

(iv)

I was always very fluent and had a large vocabulary compared to the other kids at my level. Not only had I started learning very early, but I was always very interested in music.

The narratives above have in common the fact that students started at an early age, and didn't depend on classroom teaching to learn the language. In fact, all of them relied on out-of-the-classroom resources to learn English, namely video-games, music, and also on their knack for it.

Type number 2, Learning as struggling, presents our hero/in working hard to achieve his/her goals. The hero/in in this case seeks something that he/she needs to restore the initial state of peacefulness, he is the Seeker (PROPP, 2000). ${ }^{18}$ Here is when other characters step in the story in order to help the former achieve success, the Helpers. Performing this role are teachers, materials, everyday situations, and even other students, as some of our narratives made clear. On the other hand, opposing to the Helpers and the hero/in there are the villains, also performed by materials, teachers, and situations that might hinder or even difficult the achievement of the goal,

\footnotetext{
18 Seeker, as defined by Propp (see note 15 above), is one of the functions of the dramatis personae. It makes reference to the one that goes after a seized person and, thus, becomes the hero of the story.
} 
which is acquire the target language. This proved to be the most common cases among the narratives studied, as shown in the examples below.

(i)

if I did not studied (sic) by myself I would not learn so much ...I used to read my bilingual dictionary every time I could and also translate the lyrics of songs that I liked in order to increase my vocabulary. I decided to watch films with subtitles instead of seeing those dubbed ones.

(ii)

my first contact with the English language was when I was about 11 (at school)... but the classes were horrible, and I decided to look for other ways to learn...

(iii)

I tried to do as much as possible studying at home, I heard lots of tapes and watched lots of films and also started to enroll on English course only at the university. I must say that I improved considerable during one year.

Students in this group, as shown above, expressed awareness that unless they went for it themselves, they would not learn the language. It is clear from the examples that they took responsibility for their learning process, even though such decision was made unconsciously on the basis of just reaching the defined goal.

Though there may be a lot of effort put on towards achieving the goal, the hero/in finds pleasure in their quest. Obstacles are disregarded in favor of the language to be achieved.

The next type, Learning as infatuation, presents narratives that highlight the learners' love for the language. They are illustrated as follows:

(i)

Although the classes were boring and all the same, I managed to make the most of them. I have always been a passionate language learner and I guess that this passion for learning helped me become a very autonomous learner.

(ii)

I started learning English at the age of 8. Since I was a child I was fascinated about English and felt a great pleasure in studying it. During all my English lifetime I studied at an English private school, which is the place where I work nowadays as an English teacher 
(iii)

When I was a teenager, I loved studying English because my classes were fun! I could speak about myself, teachers gave us many topics to discuss in groups, there were many games and videos to watch, all the activities that I did not have at elementary school. I remember I felt pretty confident to speak in class, what is interesting is: I was a shy girl!

Students above used strong words to show how much they wanted to learn the language - passionate, fascinated, and love. Once again, the group showed awareness and autonomy regarding what they wanted. Problems, as discussed above, didn't seem to matter much to them. In fact, many times they worked as a motivational factor to achieve their intent. We can see that in all the narratives they report having achieved their goal and gained confidence as a result.

The next group of examples show the fourth type of learning sequence proposed by Leppänen; Kalaja's ( $i b i d$ ), Learning as suffering. Here, the hero/in finds it extremely difficult to walk down the path to achieve his/ her goal, and places himself/herself as the Victimized Hero (PROPP, ibid).

(i)

Once upon a time, there was a little girl called Alexandra. ... Her mother, who didn't know anything about psychology, thought that if she compared Alexandra to her sister... and Alexandra was getting more and more insecure. Alexandra wasn't a good student at all. With the constant comparisons with her sister, Alexandra started to hate English.

(ii)

The beginning was hard, because the course was not made for novices, and I felt shy among people that knew the language a lot. I had lots of problems with my grades and I thought it was impossible to learn that language.

(iii)

Learn (sic) a foreign language is not an easy task and sometimes it is also traumatic. My incursion into English territory was no different.

(iv)

Mistakes were punished by bad grades. I felt that I was never able to learn English. I got completely blocked and sometimes I put myself down unable to learn the stuff proposed. For several times I thought I would never learn the amount of rules presented by the teacher every week to the scared class. 
These examples show the opposite feeling experienced by the previous group. Students not only felt discouraged to go on their path but also had classes, methods, parents, and so forth as the Villains (PROPP, ibid) ${ }^{19}$ of their quests. The fairy tale structure can be clearly seen in example (i) above as the student's intent to reinforce her struggle and make her story clearer to the reader.

The last type presented by Leppänen; Kalaja's ( ibid), Learning as a by-product, shows, as already discussed here, our hero/in seeking English proficiency as a means to achieve something else they consider bigger than proficiency itself. The language is a mere instrument used in such venture. Thus, according to Leppänen; Kalaja's ( $i b i d$ ), the role performed is that of the Antibero (PROPP, ibid). ${ }^{20}$

(i)

I always got interested in songs sung in English, not in Portuguese. For you to have an idea, I do not have any CDs by Brazilian artists. Mainly are by British and American artists. A lot of people find it very strange. Later on, when I was eight, I started buying international soundtracks of soap operas. I listened to them for hours.

(ii)

However, the sport I have been practicing from that period so far is full of English words and expressions, what made me more interested in English. In fact skateboard has been a 'catapult' to my English learning process.

\section{Conclusion}

All the linguists mentioned in the paper, like Bakhtin (1988), consider language not only as the starting point of identity discussion, but also as something to be performed socially, though it can be mastered on an individual basis. The examples selected showed precisely how important and inherent the social environment is in the FL/SL learning process.

Identity is a natural definition of how we see the world and ourselves, and mainly how we use the artifacts available to us in order to express our

${ }^{19}$ Villain (PROPP, 1968) is the agent whose role is to disturb the peace and cause some form of misfortune, damage, or harm (See note 15 above ).

${ }^{20}$ Antibero (PROPP, 1968) is another name given to the villain (See note 15 above). 
views. In this respect, as shown in the present study, language is the resource we have at hand to do such a task. Language is a means of communication, interaction with ourselves and the others. Even, as seen, when we lose our identities in order to achieve a new one in the language to be learned, we are going under a process of identity construction. This was exactly what this study observed in the narratives used by AMFALE learners to express what learning a second language meant to them.

Placing themselves like heroes in a fairy tale in their quest for the ultimate fluency in the English language, who had to overcome the most varied obstacles to get the promising reward, they tried to make us see how difficult but pleasant and rewarding the $\mathrm{L} 2$ process can be. In their effort to do so, students find the narrative model to be more comfortable than any other approach that might be used to report their experiences, since we all are used to hearing and telling stories since an early age. We are familiar with the fairy tale pattern. In this light, teachers, materials, classmates, and even parents can, at times, play the role of Helpers who will find a way to make the hero's quest less struggling, and Villains, at others, when, then, they will make it harder for the hero to reach his/her goal. It is like Tolson, cited by Leppänen; Kalaja's ( $i b i d$ ), put it: "formulaic narratives such as fairy tales reduce the unique or the unusual to familiar and regular patterns of expectation". ${ }^{21}$ However, despite problems faced along the way, learners seemed to agree with Gergen (1997) and "see the final goal as having great value". It is not only the process itself that appeals to them, but also what it implies, that is, social interaction. Teachers and methodologies seem to play an especially important role in the process as motivational factors who will push them into achieving their goal. Being able to reach the conversational level makes them confident enough to start expressing their ideas and feel they are understood and respected by others. For them, mastering the language meant getting the professional status they ambitioned, the place in a university, placing themselves in the world's scenario, and also as important, a personal recognition and a recognition by others of their capacity of meeting challenges.

${ }^{21}$ TOLSON. Mediations: Text and Discourse in Media Studies.London: Ardold, 1996. 


\section{References}

BAKHTIN, M. Marxismo e filosofia da Linguagem. São Paulo: Hucitec, 1988. BAMBERG, M. Construindo A masculinidade na adolescência: posicionamentos e o processo de construção da identidade aos 15 anos. Trad. Cláudia Buchweitz. In: LOPES, L.P.M.; BASTOS, L.C. (Org.). Identidades - recortes multi e interdisciplinares. Campinas (SP): Mercado das Letras, 2002. p. 149-185.

BARTHES, R. The Structuralist Activity. In: Critical Essays. Trans. R. Howard. Evanston, Ill: Northwestern University Press, 1972

BROCKMEIER, Jens; HARRE, Rom. Narrativa: problemas e promessas de um paradigma alternativo. Psicol. Reflex. Crit., Porto Alegre, v. 16, n. 3, 2003. Disponível em: <http://test.scielo.br/scielo.php?script=sci_arttext\&pid= S0102-79722003000300011\&lng=pt\&nrm=iso>. Acesso em: 24 set. 2006.

CAMERINI, M.F.A.; SOUZA, S. J. Interatividade audiovisual e produção da subjetividade. In: LOPES L. P. M.; BASTOS, L.C. (Org.). Identidadesrecortes multi e interdisciplinares. Campinas (SP): Mercado das Letras, 2002. p.389-402.

CARVALHO, I. C. M. Biografia, identidade e narrativa: elementos para uma análise hermenêutica. Horiz. antropol., Porto Alegre, v. 9, n. 19, 2003. Disponível em: $<$ http://www.scielo.br/scielo.php?script=sci_arttext\&pid= S0104-71832003000100012\&lng=en\&nrm=iso>. Acesso em: 27 ago. 2006.

CLIFFORD, J. Dilemas de la cultura. Antropología, literatura y arte en la perspectiva posmoderna. Barcelona: Gedisa, 1995.

ELLIS, R. Second Language Acquisition. Oxford: Oxford University Press, 1997.

GARDNER, R.C. Motivation and second language acquisition,1968. Disponível em: <http://publish.uwo.ca/ gardner/SPAINTALK.pdf.> Acesso em: 17 out. 2006

GERGEN, K. Narrative, moral identity and historical consciousness: a social constructionist account, 1997. Disponível em: http:<http://pegasus. cc.ucf.edu/ gallaghr/introbib.html>. Acesso em: 7 out. 2006.

GOVER, M.R. The narrative emergence of identity. Michigan University Press, 1996.

GREIMAS, A. J. Elements of a Narrative Grammar. In: On Meaning: Selected Writings in Semiotic Theory. Trans. Paul Perron and Frank Collins. Minneapolis: University of Minnesota Press, 1987. 
HAESBAERT, R. Fim dos territórios ou novas territorialidades? In: LOPES, L. P. M.; BASTOS, L. C. (Org.). Identidades-recortes multi e interdisciplinares. Campinas (SP): Mercado das Letras, 2002. p. 29-51.

LANTOLF, J.P.; PAVLENKO, A. Second language learning as participation and the (re)construction of selves. In: LANTOLF J.P. (ed.) Sociocultural theory and second language learning. Oxford: Oxford University Press, 2000. p. 189-203.

LEPPÄNEN, S.; KALAJA, P. Autobiographies as constructions of EFL learner identities and experiences. University of Jyväskylä, Finland. 2002. p. 189-203.

LUBECK, R. Talking Story: Narrative thought, worldviews and postmodernism-, 1998. Disponível em: <http://www.multnomah.edu/ worldseen/Talking_story.asp>. Acesso em: 10 jun. 2006.

MURRAY, K. Narrative Partitioning: The ins and outs of identity construction (1995). Disponível em: <http://home.mira.net/ kmurray/psych/ in\&out.html>. Acesso em: 27 abr. 2006.

PAVLENKO, A.; LANTOLF, J.P. Second language learning as participation and the (re)construction of selves. In: LANTOLF, J.P. (Ed.). Sociocultural theory and second language learning. Oxford: Oxford University Press, 2000. p. 189-203.

PROPP, V. Morphology of the folktale. Austin: University of Texas Press, 2000.

RAJAGOPALAN, K. A confecção do memorial como exercício de reconstituição do self. In: LOPES, L. P. M.; BASTOS, L. C. (Org.). Identidades - recortes multi e interdisciplinares. Campinas (SP): Mercado das Letras, 2002. p. 339-350.

SILVA, T. T. A produção social da identidade e da diferença. In: SILVA, T. T. (Org.). Identidade e diferença: a perspectiva dos estudos culturais. Petrópolis, Vozes, 2000.

URIARTE, U. M. Identidades mestiças: reflexão baseada na obra do escritor peruano José Maria Arguedas. In: LOPES, L. P. M.; BASTOS, L. C. (Org.). Identidades - recortes multi e interdisciplinares. Campinas (SP): Mercado das Letras, 2002. p. 219-232.

VEIGA-NETO, A. Michel Foucault e os estudos culturais. In: COSTA, M. V. Estudos culturais em educação. Porto Alegre: Ed. da UFRGS, 2000.

VEREZA, S. C. Quem fala por mim?:Identidade na produção discursiva em língua estrangeira. In: LOPES, L. P. M.; BASTOS, L. C. (Org.). Identidades - recortes multi e interdisciplinares. Campinas (SP): Mercado das Letras, 2002. p. 351-361. 